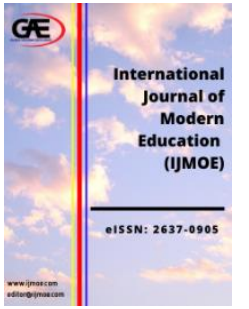

INTERNATIONAL JOURNAL OF

MODERN EDUCATION

(IJMOE)

www.ijmoe.com

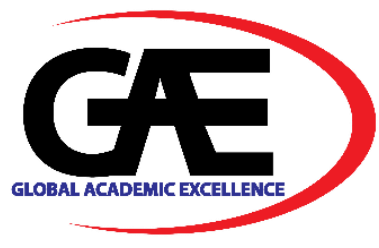

\title{
THE EFFECTS OF EMPOWERMENT ON TEACHERS' JOB COMMITMENT IN SECONDARY SCHOOLS
}

\author{
Menaga Vesudevan ${ }^{1}$ \\ 1 Center of Liberal Arts and Languages, INTI International University, Malaysia \\ Email: menaga.vesudevan@newinti.edu.my
}

\section{Article Info:}

\section{Article history:}

Received date: 15.03.2021

Revised date: 25.03.2021

Accepted date: 29.03.2021

Published date: 31.03 .2021

\section{To cite this document:}

Vesudevan, M. (2021). The Effects of Empowerment on Teachers' Job Commitment in Secondary Schools. Journal of Modern Education, 3(8), 238-244.

DOI: 10.35631/IJMOE.380019

This work is licensed under CC BY 4.0

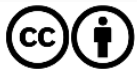

\begin{abstract}
:
The purpose of this research was to explore the effect of empowerment and teachers' job commitment. The effect of empowerment and teachers' job commitment in Malaysia not only expected and regarded as important in enhancing knowledge but also to be responsible for molding and shaping an excellent student. This research was conducted in Selangor using the quantitative research method. The total respondents of this study are 120 teachers, who teach in secondary school in Selangor. The survey questionnaire was used as the main tool for data collecting. The results of the analysis show that there is a significant relationship between the effects of empowerment and teachers' job commitment $(\mathrm{r}=.396, \mathrm{p}<.05)$.
\end{abstract}

Keywords:

Structural Empowerment, Psychological Empowerment, Job Commitment

\section{Introduction}

The understanding of teachers' empowerment has received a great competence to take charge of their own growth and resolve their own problems. The empowerment is gained through professional growth and knowledge. Meanwhile, the management practices that they adopted will led to competition among the organizations. The quality of students are proceed with the teachers' experience and commitment (Fasoyiro,2016). As a teacher they are playing an important role in schools and students' well learning process shows they are performing excellence in their studies. The quality of education will be ruined, if teachers failed to perform well in their teaching profession (Tai,Omar, Mohamad Sahari \& Khuan, 2017).The competitors Copyright $\odot$ GLOBAL ACADEMIC EXCELLENCE (M) SDN BHD - All rights reserved 


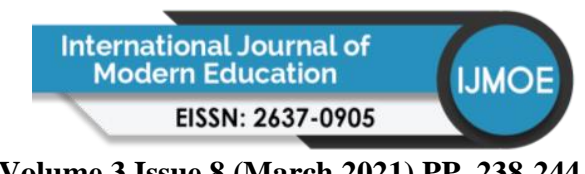

Volume 3 Issue 8 (March 2021) PP. 238-244

DOI: 10.35631/IJMOE.380019

are merged, rather than the organization more proactive among the organization (Narang and Singh, 2010). Boudrias, Gaudreau, Savoie and Morin (2009) argue that the employees are proactive that able to be increasing productivity in human resource practices. Sweetland and Hoy (2000), claimed that empowerment is very significant in all sectors, including education where is most importance to teachers' empowerment. Hence, its supported with four assumptions regarding teacher empowerment. First the teachers' professionalism are increase when teachers' empowerment became most effective. Second, empowerment able to least two dimensions, organizational and classroom environment. Then, the third one is empowering teachers' has great changes in students achievement when they emphasis the usage of ICT in learning. And, the forth part is teachers' needs to be effective on their empowerment. Teachers' empowerment is a key component in restricting schools.

\section{Literature Review}

\section{Structural Empowerment}

Structural empowerment is recognised and provides acknowledged environment for employees. The structure of opportunity defined as a form that supports employees in their professional development while the power structure defined as a form that enables them to reach and use sources within the organisation (Altınkurt et al., 2015). Structural empowerment conceived as an organisational environment (Meng et al.,2015). Teacher empowerment is a measure of teacher development in operational and pedagogical culture (Talbert, 2003). Empowerment used to express appreciation and support the educational organisations and the teachers (Bogler \& Nir, 2012).

\section{Psychological Empowerment}

Psychological empowerment is achieved by encouraging teachers to believe that their work is committed to their ability to carry out their self-determination tasks and their impact on the outcomes of their work (Boonyarit, Chomphupart \& Arin, 2010). The psychological empowerment of teachers will increase their job satisfaction and the commitment to work plays an important role in the academic and behavioural performance of teachers. The academic and behavioural performance of teachers will also motivate students to attend school, do their homework and have a positive impact on their learning.

\section{Job Commitment}

In the school environment, a greater autonomy of work commitment is needed on the basis of the school context. (Nir, 2002; Watson \& Hatton, 2002). The commitment of teachers is based on the belief and acceptance of the objectives and values of the organisation. Haris, A. (2001) Empowerment comes under the authority of the organisations by taking the right decisions on organisational issues. In addition, school cultures, one of the ways to build environments with uncertainty, stress, and high expectations, contribute to a reduction in the level of employment commitment (Easthope \& Easthope, 2000). 


\section{Methodology}

This study incorporated a quantitative research method to actually analyse the effect of empowerment on the commitment of teachers to work in secondary schools in Selangor. This study was conducted in the district of Selangor and the sample size of the study is a secondary school teacher in Selangor. According to the number of secondary schools in Selangor is 220. Likewise, the total schools involved in this study are 140 schools based on the sample size suggested by Krejcie and Morgan (1970). The use of the questionnaire may speed up the data collection process, make it cost-effective and keep the respondent's details confidential. Focus on questions about the extent of empowerment that has been practised among secondary school teachers in Selangor.

\section{Reliability of Instruments}

The study is to carry out a reliability and validity test on the items in the questionnaire. Therefore, the result indicated that the questionnaire constructed and showed good reliability Cronbach's Alpha score, which is 0.844 .

\begin{tabular}{ll}
\hline Cronbach's Alpha & N of Items \\
\hline .844 & 31 \\
\hline
\end{tabular}

\section{Findings and Analysis}

Data was successfully collected from 120 respondents, achieving a response rate of 100 . This was considered sufficient to make it possible to generalise the findings of the study among secondary school teachers in Selangor on their integration of creative teaching methods into teaching and learning.

Table 1 Demographic Background of Respondents

\begin{tabular}{lll}
\hline Factors & Frequency & Percent \\
\hline Gender & 52 & $43.30 \%$ \\
Male & 68 & $56.70 \%$ \\
Female & & \\
Age & 79 & $65.80 \%$ \\
$20-30$ & 33 & $27.50 \%$ \\
$31-40$ & 7 & $5.87 \%$ \\
$41-50$ & 1 & $0.83 \%$ \\
$51-60$ & & \\
Teaching Experience & 58 & $48.30 \%$ \\
$<5$ & 42 & $35.00 \%$ \\
$6-10$ & 14 & $11.70 \%$ \\
$11-20$ & 6 & $5.00 \%$ \\
$>20$ & & \\
& & \\
Education Qualification & 6 & $5.00 \%$ \\
Certificate & 13 & $10.80 \%$ \\
Diploma & 84 & $70.0 \%$ \\
Undergraduate & 17 & $14.20 \%$ \\
Masters graduate & & \\
Duration in Current School & & \\
\hline
\end{tabular}




\begin{tabular}{lcc} 
& $\begin{array}{c}\text { International Journal of } \\
\text { Modern Education } \\
\text { EISSN: 2637-0905 }\end{array}$ \\
& & $\begin{array}{c}\text { Volume 3 Issue 8 (March 2021) PP. 238-244 } \\
\text { DOI: 10.35631/IJMOE.380019 }\end{array}$ \\
\hline $1-3$ years & 26 & $21.70 \%$ \\
$4-6$ years & 81 & $67.50 \%$ \\
More than 6 years & 13 & $10.80 \%$ \\
Total & $\mathbf{1 2 0}$ & $\mathbf{1 0 0 \%}$
\end{tabular}

Table 1 above, $56.70 \%$ of respondents were females higher than males. $65.80 \%$ of respondents were between the ages of 20 and 30 . The results show that $48.30 \%$ of respondents had more than 5 years of teaching experience. The findings show that the high respondents are those with Master's degree qualifications, $14.20 \%$. Finally, the demographic results show that $21,70 \%$ of respondents have been in the current school for 1-3 years.

Table 2 Extent of Empowerment

\begin{tabular}{lllllll}
\hline & SD & $\mathbf{D}$ & $\mathbf{A}$ & $\mathbf{S A}$ & & \\
Items & $\mathbf{( \% )}$ & $\mathbf{( \% )}$ & $\mathbf{( \% )}$ & $\mathbf{( \% )}$ & Mean & S.D \\
& & & & & & \\
\hline 1. Delegation of responsibility & 56.7 & 35.8 & 7.5 & 100 & 1.51 & .635 \\
2. Participation in school & 45.8 & 46.7 & 6.7 & 0.8 & 1.62 & .649 \\
3. Rewarding teachers & 30.8 & 60.0 & 7.5 & 1.7 & 1.80 & .643 \\
4. Training teachers in basic skills & 30.0 & 49.2 & 17.5 & 3.3 & 1.94 & .781 \\
5. Training teachers in pedagogy & 40.0 & 45.0 & 11.7 & 3.3 & 1.78 & .780 \\
6. Organising team-building & 36.7 & 44.2 & 15.8 & 3.3 & 1.86 & .802 \\
7. Providing materials & 39.2 & 46.7 & 14.2 & 0 & 1.75 & .689 \\
8. Remunerating teachers & 49.2 & 38.3 & 10.8 & 1.7 & 1.65 & .741 \\
9. Encouraging teachers & 43.3 & 47.5 & 7.5 & 1.7 & 1.68 & .688 \\
10.Teachers learning & 41.7 & 50.0 & 7.5 & 0.8 & 1.67 & .650 \\
11. Participation in development & 27.5 & 47.5 & 23.3 & 1.7 & 1.99 & .761 \\
12. Involve in school budget & 30.8 & 55.0 & 9.2 & 5.0 & 1.88 & .769 \\
13. Given rights in decision making & 36.7 & 40.8 & 18.3 & 4.2 & 1.90 & .844 \\
14. Self-belief in empowering & 30.0 & 43.3 & 21.7 & 5.0 & 2.02 & .850 \\
students & & & & & & \\
15. Freedom in schedule decision & 32.5 & 42.5 & 19.2 & 5.8 & 1.98 & .869 \\
\hline
\end{tabular}

In this study shows, the extent of empowerment of secondary schools in Selangor. The high mean score is self-belief in empowering students delegate responsibilities to teachers, mean of 2.02 and a standard deviation of 0.850 . Moreover, the participation in development, mean of 1.99 and a standard deviation of 0.761 . followed by, Freedom in schedule decision, mean of 1.98 and a standard deviation of 0.869 . These are the top three dominant aspects integrated into teacher empowerment, and the items were supported by findings but maintained at a moderate level. 


\section{Commitment of Teachers}

Table 3 Extent of Job Commitment

\begin{tabular}{|c|c|c|c|c|c|c|}
\hline Items & $\begin{array}{l}\text { SD } \\
(\%)\end{array}$ & $\begin{array}{l}\text { D } \\
(\%)\end{array}$ & $\begin{array}{c}\text { A } \\
(\%)\end{array}$ & $\begin{array}{l}\text { SA } \\
(\%)\end{array}$ & Mean & S.D \\
\hline $\begin{array}{l}\text { 1. Minimal teacher } \\
\text { absenteeism }\end{array}$ & 27.5 & 35 & 15 & 22.5 & 2.32 & 1.109 \\
\hline 2. Lower teacher turnover & 26.7 & 35 & 15 & 23.3 & 2.35 & 1.113 \\
\hline 3. Teachers consult each other & 25.8 & 39.2 & 22.5 & 12.5 & 2.22 & .972 \\
\hline $\begin{array}{l}\text { 4. Teachers performance high } \\
\text { in school }\end{array}$ & 26.7 & 36.7 & 12.5 & 24.2 & 2.34 & 1.119 \\
\hline $\begin{array}{l}\text { 5. Teachers are highly } \\
\text { motivated }\end{array}$ & 35 & 45 & 15 & 5 & 1.90 & .834 \\
\hline $\begin{array}{l}\text { 6. Little supervision by } \\
\text { management }\end{array}$ & 41.7 & 45 & 11.7 & 1.7 & 1.73 & .730 \\
\hline $\begin{array}{l}\text { 7. Feel like being a part of the } \\
\text { school }\end{array}$ & 33.3 & 44.2 & 15 & 7.5 & 1.97 & .888 \\
\hline $\begin{array}{l}\text { 8. Recommend teaching } \\
\text { position }\end{array}$ & 22.5 & 50.8 & 20 & 6.7 & 2.11 & .828 \\
\hline $\begin{array}{l}\text { 9. High accountability among } \\
\text { teachers }\end{array}$ & 31.7 & 54.2 & 14.2 & 0 & 1.83 & .657 \\
\hline $\begin{array}{l}\text { 10. Teacher stay late hours in } \\
\text { school }\end{array}$ & 31.7 & 57.5 & 10.8 & 0 & 1.79 & .620 \\
\hline 11.Teacher always in school & 33.3 & 53.3 & 10.8 & 2.5 & 1.83 & .718 \\
\hline $\begin{array}{l}\text { 12. Cooperation with other } \\
\text { members of staff }\end{array}$ & 32.5 & 57.5 & 8.3 & 1.7 & 1.79 & .660 \\
\hline 13. Do things sincerely & 33.3 & 59.2 & 7.5 & 0 & 1.74 & .587 \\
\hline 14. Prepare before class & 30.8 & 55.8 & 13.3 & 0 & 1.83 & .644 \\
\hline $\begin{array}{l}\text { 15. Follow up on students' } \\
\text { progress }\end{array}$ & 39.2 & 51.7 & 7.5 & 1.7 & 1.72 & .676 \\
\hline
\end{tabular}

The study sought to determine whether teachers who monitor students' progress in school are considered to be a sign of commitment among secondary schools in Selangor. The findings as shown in Table 3 confirm that the teacher has a lower teacher turnover with a mean score of 2.35 and a standard deviation of 1.113. There is no doubt that teachers' performance high in school score high mean score the study established with the mean score of 2.34 and standard deviation of 1.119. The findings also reveal that there was minimal absenteeism among teachers with a mean of 2.32 and a standard deviation of 1.109. This confirms that most of the respondents strongly agree on their job commitment.

\section{Effect of Empowerment On Teachers' Job Commitment}

The relationship between the effect of empowerment and teachers' job commitment were explored by using the Pearson correlation test analysis. This analysis was used to determine the strength and direction of the relationship between the two independent and dependent variables. 


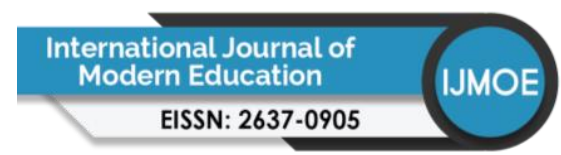

Volume 3 Issue 8 (March 2021) PP. 238-244

DOI: 10.35631/IJMOE.380019

Table 4 Correlation between Empowerment and Teachers' Job Commitment

\begin{tabular}{llll}
\hline & & Empowerment & $\begin{array}{l}\text { Commitment } \\
\text { Sum }\end{array}$ \\
\hline Empowerment & Pearson & 1 & $.396^{* *}$ \\
& Correlation & & .000 \\
& Sig. (2-tailed) & & 120 \\
& N & 120 & 1 \\
Commitment Sum & Pearson & $.396^{* *}$ & \\
& Correlation & .000 & 120 \\
& Sig. (2-tailed) & 120 & \\
& N & 120 & \\
\hline$* *$ Correlation is significant at the 0.01 level (2-tailed). & \\
\hline
\end{tabular}

Based on Table 4, empowerment was significantly linked to teachers' job commitment $[\mathrm{r}=0.396, \mathrm{n}=120, \mathrm{p}<0.05]$. Moreover, there was a strong and positively significant correlation between the two variables. However, based on the criteria of Cohen (1988) in which $r>.03$ $<.05$ are indicative for a moderate correlation. As a result, the results of the analysis show that there is a significant relationship between the effects of empowerment and teachers' job commitment hence, the null hypothesis is rejected.

\section{Conclusion}

Based on the results the creation of empowerment in a school system contributes to the productivity of teachers. Basically, empowerment is shown to be the process by which schools provide space to develop the competence of teachers to advance themselves and solve their own problems. In addition, teachers who have been empowered to believe that they have the skills and knowledge to act on the situation and to make improvements. These schools exist in schools which provide them with the opportunity to develop and demonstrate their competence. From here, there are certain ways to reflect the empowerment of teachers. The results show that committed teachers spend long hours in school on a voluntary basis. This study found that involving teachers in decision-making at school is one of the ways that secondary schools in Selangor use to empower teachers. From the regression results it's concluded that there are significant relationships between two variables on the effects of empowerment of teachers on their job commitment. As an evident it's a great significant effect on the empowering and teachers job commitment of secondary schools in Selangor. The study also showed that secondary schools in Selangor empower their teachers by encouraging them to pursue further education; by training them in pedagogy and by organising team building activities.

\section{References}

Altınkurt, Y., Ertürk, A., \& Yılmaz, İ. (2015). Öğretmenlerin psikolojik sermayeleri ile tükenmişlik düzeyleri arasındaki ilişki. Öğretmen Eğitimi ve Eğitimcileri Dergisi, 4(2), 166-187.

Bogler, R. \& Somech, A. (2004). Influence of teacher empowerment on teachers' organizational commitment, professional commitment and organizational citizenship behavior in schools. Teaching and Teacher Education, 20(3), 277-289. http://dx.doi.org/10.1016/j.tate.2004.02.003

Bogler, R., \& Nir, A. E. (2012). The importance of teachers' perceived organizational support to job satisfaction: What's empowerment got to do with it? Journal of Educational Administration,50(3), 287-306. 


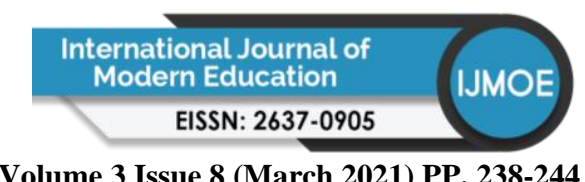

Volume 3 Issue 8 (March 2021) PP. 238-244 DOI: 10.35631/IJMOE.380019

Boudrias, J. Gaudreau, P, Savoie, A and Morin, AJS 2009, Employee Empowerment: From Managerial Practices to Employees' Behavioral Empowerment, Leadership and Organization Development Journal, Vol.30, No.7, pp.625-638.

Boonyarit, I., Chomphupart, S., \& Arin N. (2010). Leadership, empowerment, and attitude outcomes. The Journal of Behavioral Science, 5(1), 1- 14.

Cohen, J. (1988). Statistical Power Analysis for the Behavioral Sciences (2nd ed.). Hillsdale, NJ: Lawrence Erlbaum Associates, Publishers.

Easthope, C. and Easthope, G. (2000). Intensification, extension and complexity of teachers' workload. British Journal of Sociology of Education, vol 21, no 1 pp 43-58.

Fasoyiro, O.(2016). Developing as a teacher: A study of Nigerian teachers,45-53. Retrieved from epapers.bham.ac.uk/2141/1/Fasoyiro.pdf.

Harris, A. (2001). "Improving Schools through Teacher Leadership."Educational Journal, Issue 59 p 22-23.

Krejcie, R.V., \& Morgan, D.W. (1970). Determining Sample Size for Research Activities. Educational and Psychological Measurement, 30, 607-610.

Meng, L., Liu, Y., Liu, H., Hu, Y., Yang, J., \& Liu, J. (2015). Relationships among structural empowerment, psychological empowerment, intent to stay and burnout in nursing field in mainland China - based on a cross-sectional questionnaire research. International Journal of Nursing Practice, 21(3), 303-312.

Narang, L. and Singh, Lakhwinder (2010), 'Human Resource Practices in Indian Organizations: $\quad$ An Empirical Study', Management and Labour Studies, 35(1): 25- 34.

Nir, A. E. (2002). School- based management and its effect on teacher commitment. International Journal of Leadership in Education, 5(4), 323-341 (2) (PDF) Relationship of Teacher Competence with Professional Commitment and Job Satisfaction at Secondary Level.

Sahoo, C. K. Kumar, N. and Tripathy, S. K. (2010), Employee Empowerment and Individual Commitment: An Analysis from Integrative Review of Research.Employment Relations 10 (1) Spreitzer, G.M. (2007), 'Towards the Integration of two Perspectives: A Review of Socio-structural and Psychological Empowerment at Workplace', in Cooper, C. and Barling, J. (eds.), Handbook of Organisational Behaviour, Thousand Oaks,CA: Sage Publications.

Sweetland, S. R., \& Hoy, W. K. (2000), School characteristics and educational outcomes: Toward an organizational model of student achievement in middle schools. Educational Administration Quarterly, 36(5), 703-729.

Tai, M. K., Omar, A. K., Mohamad Sahari, N., \& Khuan, W. B. (2017). Principal change leadership competencies and teacher attitudes toward change: the mediating effects of teacher change beliefs. International Journal of Leadership in Education, 1-20.

Talbert, T. L. (2003). Come to the edge: Embracing teacher empowerment for the 21st Century Action in Teacher Education, 25(2), 51-55. http://dx.doi.org/10.1080/01626620.2003.10463305. 